\title{
Screening of Maize Genotypes for Drought Tolerance Related Trait Variability
}

\author{
I.A. Dar* , P.A. Sofi, Z.A. Dar, Kamaluddin and A.A. Lone \\ Division of GPB, FoA/RRS Wadura (SKUAST-Kashmir), India \\ *Corresponding author
}

\begin{tabular}{|l|}
\hline K e y w o r d s \\
Drought, Root \\
traits, Greenhouse, \\
Root biomass, \\
Shoot biomass
\end{tabular}

\section{A B S T R A C T}

Plant roots play an important adaptive role in drought prone environments. Although there have been many efforts to improve root traits to develop drought tolerant maize varieties but significant progress has not yet been made mainly due to difficulty in screening root traits. The aim of the study was to develop an easy and reliable screening method for deep root mass and related root/shoot traits of maize in greenhouse and evaluate their association with the grain yield under water-deficit conditions. The present study was conducted in the green house facility at the Division of Genetics and Plant Breeding, Faculty of Agriculture, Wadura. Thirteen released varieties of maize were evaluated in the present study under drought and irrigated conditions. Highest rooting depth under drought was shown by C-4 $(126.50 \mathrm{~cm})$. Recorded highest recorded Root biomass under drought was for C-15 (40.50 g). Root biomass at bottom was recorded highest under drought for GM-6 (0.414 g). Root shoot ratio was recorded highest under drought for C-15 (0.764). Under drought most of the traits had decreased value except for root biomass at bottom and shoot to total biomass which had higher values under drought. The highest percentage decrease was observed for root biomass (70.891) followed by shoot biomass (67.759) and plant height (27.120) while, as lowest percent decrease was recorded in case of shoot to total biomass (3.484). The traits root biomass at bottom and root shoot ratio had increased values under drought 28.463 and 9.388 respectively.

\section{Introduction}

Maize is one of the most important cultivated grain crops around the world and is widely used to provide food, forage, and industrial raw materials. Due to rapid changes in populations, society, and economies, the demand for maize is expected to be higher than for wheat or rice by 2020 (Pingali, 2001). The productivity and yield of maize are frequently limited by various biotic and abiotic stress factors, such as drought, salinity, high and low temperatures, nutrient deficiencies, disease, and insect pests. Drought stress can affect yield through different mechanisms across the whole life cycle of the maize plant (Leach et al., 2011). Therefore, drought is one of the most serious causes of productivity loss. Drought tolerance is a complex trait (Quarrie, 1996) involving a number of morpho-physiological traits, including root characters (Ludlow and Muchow, 1990; Tuberosa et al., 2002). It can be achieved in a number of ways, including 
drought avoidance or desiccation prevention, or combination of both, or through effective use of limited water supply, or through recovery of growth following rehydration after drought stress (Chaves et al., 2003; Passioura, 2012). Under drought stress, plants seek to reduce the impact of the lack of water by reducing the transpiration rate and by increasing the efficiency of water acquisition from the soil (Vegh, 2013). Plants have developed numerous adaptive mechanisms for better growth under drought conditions such as modification of the root system, osmotic adjustments, stomatal regulation, chemical production, and accumulation. The root system not only supports the above ground organs of the plant but also plays a crucial role in obtaining water by accessing sources far down in the soil profile. The roots are the first organs to sense a water shortage (Trachsel et al., 2010). The root system is therefore generally considered as the most important organ with respect to improving crop adaptation to water stress (Vadez, 2014).

Maize responds to drought stress by redirecting root growth and dry matter accumulation away from the shoot to the root (Ribaut et al., 2009, Sharp et al., 2004). In maize, this shift involves an increase in root cell wall extensibility that is mediated by increased levels of xyloglucan endotransglucosylases/ hydrolases and other cell wall-loosening factors at the root tip. These modifications result in sustained growth of the root and inhibited growth of the shoot in the face of decreased water potential (Ober and Sharp, 2007). A deep root system with thick roots and extensive branching ability is considered a major component of drought avoidance, enabling the plants to extract water from deep soil layers (Fukai and Cooper, 1995; Gowda et al., 2011). Root characteristics, particularly root depth, are likely to increase plant water uptake, and therefore, these play a role in dehydration avoidance mechanisms and crop resistance to drought (Serraj et al., 2009). Root traits associated with maintaining plant productivity under drought include roots with small fine root diameters, long specific (main/laterals) root length, and considerable root length density, especially at soil depths with available water (Comas et al., 2013). Crop plants with deep and very extensive root systems could simultaneously improve both soil structure and its steady-state carbon, water and nutrient retention, as well as sustainable yields (Kell, 2011). Root morphology is a poorly studied maize characteristic due to the difficulties of making direct measurements under the soil and also of observing or removing roots of plants grown under agronomic conditions. Genetic improvement to produce deep-rooted plants is considered an important strategy for improving water capture and yield stability (Kondo et al., 2003). Variation in root system architecture can be explored to improve plant vigor by improving water use efficiency and nutrient extraction under difficult growing conditions (Malamy and Benfey, 1997). In the root system of maize, lateral roots are of major importance for the efficient short-distance exploitation of water and nutrients (McCully 1999), and they make up about eight times the surface area of their parental axile roots and take up about eight times as much water. In response to evapotranspiration demands, shoots drive water uptake through a root system (Comas et al., 2013) and amount of water uptake is determined by root architecture, i.e., root angles, rooting depth, root diameter, number of root branches and length of root hairs (Lynch, 2013). Wasson et al., (2012) proposed selection on the traits to improve root systems and water uptake in water-limited wheat crops, which includes deep roots, greater root branching at median and deeper soil layers, reduced root length density near the surface, and longer root hairs with increased xylem diameter for decreased 
resistance to water movement from soil to roots. Burton et al., (2013) reported that maize landraces have greater variation in root architectural traits and have longer nodal roots and larger xylem than related wild Zea species. Longer roots were shown to assist in the capture of mobile resources in the soil and are considered to be a primary determinant of drought tolerance in maize (Zhu et al., 2010). Hund et al., (2009) observed greater rooting depth in the drought tolerant tropical maize inbred lines than the sensitive lines.

Studying roots extensively under field conditions is still limited due to the expenditure of time involved in destructive techniques like the core method and the likelihood of under-estimation of root depth and density. Using PVC tubes in greenhouse, phenotypic variation in maize root traits, such as root length, root thickness, total root mass, deep root mass, deep root ratio and deep root to shoot ratio are evaluated. In the present study, we aimed to i) assess the natural variation for root architectural traits and biomass partitioning in maize genotypes under drought conditions (ii) identify root related traits accounting for most of the variation under drought conditions.

\section{Materials and Methods}

\section{Plant material}

The present study was conducted at the green house facility of the Division of Genetics and Plant Breeding, Faculty of Agriculture Wadura, SKUAST-K Sopore. Thirteen varieties of maize were evaluated in the present study viz., Shalimar maize composite4 (C-4), C-6, C-8, C-15, Shalimar maize composite -7 (KDM-72), Kishan Ganga-1 (KG-1), Kishan Ganga-2 (KG-2), Pratap Makka -3 (PM-3), Pratap Makka-4 (PM-4), Pratap Makka-5 (PM-5), Pratap Makka-Chari6 (PM Chari-6), Aravali Makka-1 (AM-1),
Gujrat Makka-6 (GM-6) in well-watered (WW) and water-deficit (WD) conditions.

\section{Column culture experiment}

The experiment was conducted under ambient temperature to prevent the confounding effects on account of heat stress. The plants were grown in PVC root columns of dimensions 1.3 meter height and $20 \mathrm{~cm}$ internal diameter in a completely randomised design with three replications each for drought and irrigated treatments. Initially four seeds each were sown after surface sterilisation with $10 \%$ $\mathrm{NaOCl}$ for 5 minutes and subsequent rinsing by distilled water. After the plants reached the four leaf stage, only two competitive plants per column were maintained. Drought was imposed at first fully expanded leaf stage by withholding water in drought treatment while as irrigated treatment was regularly watered. The roots and shoots were harvested after 48 days of sowing.

\section{Analysis of root and shoot biomass parameters}

Roots were carefully harvested from columns and the soil from each column was sieved to derive all possible root fractions for unbiased estimate of root biomass. The roots thus harvested were washed with a mild detergent solution to remove sand and other impurities, rinsed with tap water to remove excess soap and dried in shade and weighed for root biomass fraction. Roots were carefully separated from the growing medium without any breakage in the root system. The shoots of each plant were separated by cutting at the base of the stem. After removing shoots, roots were laid on a flat surface and stretched to measure their length (from the base of the stem to the tip of the root system) as an estimate of rooting depth. Roots were also cut into two equal sections to estimate the biomass allocation in different zones. Data on 
various parameters were recorded such as rooting depth, root volume, root biomass, shoot biomass, root/shoot biomass ratio and differential root biomass partitioning. The design used was CRD.

\section{Results and Discussion}

\section{Root traits under greenhouse conditions}

The data pertaining to various root and shoot parameters under drought and irrigated conditions is presented in Table 1 (Figure 1) reveled that under drought plant height was highest in C-8 $(111.00 \mathrm{~cm})$ followed by C-15 $(107.50 \mathrm{~cm})$ and KDM-72 $(107.00 \mathrm{~cm})$ and was lowest in GM-6 $(93.50 \mathrm{~cm})$ and PM-5 $(93.50 \mathrm{~cm})$, while as under irrigated conditions it was highest in C-8 $(161.00 \mathrm{~cm})$ followed by KG-1 $(153.00 \mathrm{~cm})$ and C-6 $(147.00 \mathrm{~cm})$ and was lowest in C-15 $(117.00 \mathrm{~cm})$ and GM-6 $(117.00 \mathrm{~cm})$. Under drought shoot biomass was highest in C-8 (83.00 g) followed by C-6 $(73.00 \mathrm{~g})$ and KDM-72 (65.00 g) and was lowest in KG-1 (35.00 g) and PM Chari-6 $(35.00 \mathrm{~g})$, while as under irrigated conditions it was highest in C-6 (210.00 g) followed by C-4 (208.00 g) and C-8 (183.00 g) and was lowest in PM-4 (116.00 g). Under drought root depth was highest in C-4 $(126.50 \mathrm{~cm})$ followed by PM Chari-6 $(113.50 \mathrm{~cm})$ and Aravali Makka-1 $(113.00 \mathrm{~cm})$ and was lowest in KG-2 $(62.50 \mathrm{~cm})$, while as under irrigated conditions it was highest in PM-4 $(156.00 \mathrm{~cm})$ followed by C-8 $(154.00 \mathrm{~cm})$ and C-6 (141.50 $\mathrm{cm})$ and was lowest in PM-5 $(92.50 \mathrm{~cm})$. Under drought root biomass was highest in C$15(40.50 \mathrm{~g})$ followed by KDM-72 (34.50 g) and PM-4 (31.50 g) and was lowest in PM-5 $(17.00 \mathrm{~g})$, while as under irrigated conditions it was highest in PM-4 (105.50 g) followed by Aravali Makka-1 $(95.50 \mathrm{~g})$ and C-15 (94.50 g), PM-3 (94.50 g) and was lowest in KG-2 $(62.50 \mathrm{~g})$. The results from this study demonstrated that water stress throughout maize development significantly affected maize growth processes, resulting in a sharp decrease in plant height, leaf area, stem diameter, biomass accumulation, and root traits also. Drought caused a decrease in plant height, shoot biomass, root depth and root biomass. Under water-stressed conditions, maize lines with different genetic backgrounds and origins displayed different drought tolerance capabilities and showed varied root architecture traits at the seedling stage (Kumar et al., 2012; Liang et al., 2013). Hund et al., (2009) observed greater rooting depth in the drought tolerant tropical maize inbred lines than the sensitive lines. An inverse relationship between rooting depth and available soil water was reported in maize under field conditions (Dwyer et al., 1988). Earlier Ogawa et al., (2005) also reported declined root length and roots density in maize in water deficit environment. Eggball and Maranville (1993) reported that root weight and length of maize cultivars differed among genotypes. The genotype with the greatest amount of roots deep in the soil had highest grain yield. Severe water stress reduced the root mass and length in the green house. Overall, our experimental results suggest that root length, deep root mass and total root mass are related and are implicated with drought tolerance, but deep root mass could be used as a more reliable trait for selection for drought tolerance in maize. Further studies in greenhouse and in fields as well are required using a larger panel of genotypes to validate this kind of association.

\section{Biomass partitioning under greenhouse conditions}

The data pertaining to various root and shoot parameters under drought and irrigated conditions is presented in Table 2 reveled that under drought root to total biomass was highest in C-15 (0.429 g) followed by PM-4 $(0.408 \mathrm{~g})$ and PM Chari-6 (0.401 g) and was lowest in C-6 (0.215 g), while as under 
irrigated conditions it was highest in PM-4 $(0.488 \mathrm{~g})$ followed by C-15 (0.415 g) and PM$3(0.415 \mathrm{~g})$ and was lowest in C-6 (0.279 g). Under drought shoot to total biomass was highest in C-6 (0.793 g) followed by C-8 $(0.755 \mathrm{~g})$ and PM-3 (0.699 g) and was lowest in C-15 (0.569 g), while as under irrigated conditions it was highest in C-6 $(0.720 \mathrm{~g})$ followed by C-8 (0.707 g) and KG-2 (0.697 g) and was lowest in PM-4 (0.511 g). Under drought root shoot ratio was highest in C-15 (0.764) followed by PM-4 (0.691) and PM Chari-6 (0.671) and was lowest in C-6 (0.282), while as under irrigated conditions it was highest in PM-4 (0.987) followed by PM-3 (0.714) and C-15 (0.712) and was lowest in C6 (0.387). Under drought root biomass at top was highest in PM-5 (0.826 g) followed by Aravali Makka-1 (0.776 g) and KG-1 (0.770 g) and was lowest in GM-6 (0.585 g), while as under irrigated conditions it was highest in PM Chari-6 (0.935 g) followed by GM-6 $(0.893 \mathrm{~g})$ and $\mathrm{C}-15(0.799 \mathrm{~g})$ and was lowest in KG-1 $(0.600 \mathrm{~g})$. Under drought root biomass at bottom was highest in GM-6 $(0.414 \mathrm{~g})$ followed by C-15 (0.395 g) and KG$2(0.392 \mathrm{~g})$ and was lowest in PM-5 (0.124 g), while as under irrigated conditions it was highest in KG-1 (0.399 g) followed by PM-5 $(0.273 \mathrm{~g})$ and $\mathrm{KG}-2(0.256 \mathrm{~g})$ and was lowest in PM Chari-6 (0.064 g). Root: shoot ratio increases dramatically under drought conditions suggesting that functional responses to reduced soil moisture primarily occur through increased growth of roots, as has been shown suggested by Quezada and Gianoli (2010). Similarly, Huang et al., (2013) also reported that deficiencies of soil water resulted in high root: shoot ratio. Relatively, more biomass was allocated to the root than to the shoot, and plant allocated more resource to the belowground growth. The same pattern of partitioning has also been observed in other plants (Gonzales et al., 2008). In response to evapotranspiration demands, shoots drive water uptake through a root system (Comas et al., 2013) and amount of water uptake is determined by root architecture, i.e., root angles, rooting depth, root diameter, number of root branches and length of root hairs (Lynch, 2013). Changes in biomass partitioning under stress determine plants ability to respond to environmental changes that alter resource availability and plants invariably respond by increasing its efficiency of the resource that tends to limit plant growth and finally change its yielding ability. Recently, there has been greater emphasis on remobilization of photosynthates from vegetative parts such as shoot to cob and then from cob on to grains, as an important mechanism of drought resistance (Rao et al., 2012). Aslam et al., (2013) concluded that stem elongation in maize under water stress was reduced during vegetative period.

Characterization of maize germplasm with better stress tolerance traits and screening for drought tolerant maize lines are essential to the success of breeding programs. A deep root system with thick roots and extensive branching ability is considered a major component of drought avoidance, enabling the plants to extract water from deep soil layers (Fukai and Cooper, 1995; Gowda et al., 2011). Burton et al., (2013) reported that maize landraces have greater variation in root architectural traits and have longer nodal roots and larger xylem than related wild Zea species. Longer roots were shown to assist in the capture of mobile resources in the soil and are considered to be a primary determinant of drought tolerance in maize (Ribaut et al., 2009; Zhu et al., 2010). However, moderate water stress in the field, significantly increased root length. Changes in biomass partitioning under stress determine plants ability to respond to environmental changes that alter resource availability and plants invariably respond by increasing its efficiency of the resource that tends to limit plant growth and finally change its yielding ability. 
Effect of drought on root traits and biomass partitioning

The factorial ANOVA for root and biomass and biomass partitioning is presented in Table 3 . The mean square due to genotypes was significant for all traits except plant height and root depth. The mean square due to water regime was significant for all the traits studied. The first order interaction of genotype $\mathrm{x}$ water treatment was significant for root depth, root biomass, percent root biomass at top and percent root biomass at bottom, while it was non-significant for all other traits.

The data pertaining the effect of drought on various root and shoot traits and biomass partitioning is presented in Table 4 reveled that percent increase were highest recorded for root biomass at bottom and root shoot ratio. The data revealed that under drought most of the traits had decreased value except for root biomass at bottom and root shoot ratio which has higher values under drought.

The highest percentage decrease was observed for root biomass (70.891) followed by shoot biomass (67.759) and plant height (27.120) while, as lowest percent decrease was recorded in case of shoot to total biomass (3.484). The traits root biomass at bottom and root shoot ratio had increased values under drought 28.463 and 9.388 respectively. Huang et al., (2013) reported that deficiencies of soil water resulted in high root: shoot ratio. Relatively, more biomass was allocated to the root than to the shoot, and plant allocated more resource to the belowground growth. The same pattern of partitioning has also been observed in other plants (Gonzales et al., 2008).

The decrease to shoot in allocation may be beneficial to plant water economy during drought stress because the reduction of leaf area accomplishes a typical response of plants to diminish drought stress: the reduction of transpiring surface (Grace, 1997). There can be substantial and stable differences between species and varieties in the patterns of dry matter allocation to roots and in root system architecture (de Dorlodot et al., 2007). Under some conditions these differences can be clearly related to crop performance (Manschadi et al., 2006). Wasson et al., (2012) stated that maximum rooting depth and shifting of rooting density to deeper layers were most relevant root traits for yield under rainfed conditions. On the other hand, Vadez et al., (2008) could not establish desirable correlation between root length density distribution and water uptake in tropical residual moisture environment for groundnut and as such proposed to focus on root functionality via water uptake and to only subsequently characterize root morphological differences between genotypes. Another major issue to create a framework for large scale use of root architecture as a selection trait is that not all the studies conducted have reported correspondence between better rooting ability and water uptake and better yields. However, Beebe et al., (2014) has reported that deeper roots alone are not sufficient to confer drought resistance if not combined with other traits.

\section{Correlation of root and shoot parameters under drought and irrigated conditions}

The data pertaining to correlation for root and shoot parameters under drought and irrigated conditions are presented in Table 5.

\section{Positive correlations}

\section{Plant height}

Under drought condition plant height had significant positive correlation with root biomass (0.719) followed by shoot biomass $(0.675)$ and root biomass at bottom (0.181). 
Table.1 Mean performance of maize genotypes for various root and shoot parameters under drought and irrigated conditions

\begin{tabular}{|c|c|c|c|c|c|c|c|c|}
\hline \multirow[t]{2}{*}{ Genotypes } & \multicolumn{2}{|c|}{ Plant Height (cm) } & \multicolumn{2}{|c|}{ Shoot biomass (g) } & \multicolumn{2}{|c|}{ Rooting Depth (cm) } & \multicolumn{2}{|c|}{ Root biomass (g) } \\
\hline & Irrigated & Drought & Irrigated & Drought & Irrigated & Drought & Irrigated & Drought \\
\hline KDM-72 & 143.50 & 107.00 & 155.00 & 65.00 & 134.00 & 109.50 & 80.50 & 34.50 \\
\hline C-8 & 161.00 & 111.00 & 183.00 & 83.00 & 154.00 & 102.00 & 75.50 & 26.50 \\
\hline KG-1 & 153.00 & 95.00 & 144.00 & 35.00 & 114.50 & 98.00 & 67.50 & 17.50 \\
\hline C-6 & 147.00 & 98.50 & 210.00 & 73.00 & 141.50 & 99.00 & 81.50 & 18.50 \\
\hline AM-1 & 146.50 & 98.50 & 182.00 & 57.00 & 126.00 & 113.00 & 95.50 & 24.50 \\
\hline PM Chari-6 & 142.00 & 99.50 & 177.00 & 35.00 & 106.50 & 113.50 & 92.50 & 23.50 \\
\hline PM-4 & 125.50 & 103.50 & 116.00 & 45.50 & 156.00 & 100.50 & 105.50 & 31.50 \\
\hline C-15 & 117.00 & 107.50 & 133.00 & 54.00 & 122.50 & 98.50 & 94.50 & 40.50 \\
\hline GM-6 & 117.00 & 93.50 & 135.00 & 44.00 & 134.00 & 111.50 & 84.50 & 26.50 \\
\hline PM-3 & 132.50 & 96.00 & 135.00 & 41.00 & 127.50 & 96.50 & 94.50 & 17.50 \\
\hline PM-5 & 139.00 & 93.50 & 164.00 & 39.00 & 92.50 & 110.50 & 91.50 & 17.00 \\
\hline KG-2 & 134.50 & 102.00 & 147.00 & 54.00 & 134.00 & 62.50 & 62.50 & 25.50 \\
\hline C-4 & 133.50 & 100.50 & 208.00 & 48.00 & 115.00 & 126.50 & 90.50 & 21.50 \\
\hline Mean & $\mathbf{1 3 7 . 8 5}$ & 100.46 & 160.69 & 51.81 & 127.54 & 103.19 & 85.88 & 25.00 \\
\hline C.D $(p \leq 0.05)$ & \multicolumn{2}{|c|}{16.112} & \multicolumn{2}{|c|}{36.403} & \multicolumn{2}{|c|}{26.798} & \multicolumn{2}{|c|}{7.105} \\
\hline
\end{tabular}

Table.2 Mean performance of maize (Zea mays L.) genotypes for biomass partitioning under different water regimes and effect of drought under greenhouse screening

\begin{tabular}{|c|c|c|c|c|c|c|c|c|c|c|}
\hline \multirow[t]{2}{*}{ Genotypes } & \multicolumn{2}{|c|}{ Root to total biomass } & \multicolumn{2}{|c|}{ Shoot to total biomass } & \multicolumn{2}{|c|}{ Root shoot ratio } & \multicolumn{2}{|c|}{ Root biomass at top } & \multicolumn{2}{|c|}{ Root biomass at bottom } \\
\hline & Irrigated & Drought & Irrigated & Drought & Irrigated & Drought & Irrigated & Drought & Irrigated & Drought \\
\hline KDM-72 & 0.344 & 0.346 & 0.655 & 0.653 & 0.526 & 0.530 & 0.764 & 0.724 & 0.235 & 0.275 \\
\hline C-8 & 0.292 & 0.244 & 0.707 & 0.755 & 0.414 & 0.324 & 0.768 & 0.757 & 0.231 & 0.242 \\
\hline KG-1 & 0.319 & 0.353 & 0.680 & 0.645 & 0.469 & 0.573 & 0.600 & 0.770 & 0.399 & 0.229 \\
\hline C-6 & 0.279 & 0.215 & 0.720 & 0.793 & 0.387 & 0.282 & 0.752 & 0.732 & 0.247 & 0.267 \\
\hline AM-1 & 0.343 & 0.316 & 0.656 & 0.683 & 0.523 & 0.473 & 0.760 & 0.776 & 0.239 & 0.224 \\
\hline PM Chari-6 & 0.349 & 0.401 & 0.650 & 0.597 & 0.542 & 0.671 & 0.935 & 0.702 & 0.064 & 0.297 \\
\hline PM-4 & 0.488 & 0.408 & 0.511 & 0.592 & 0.987 & 0.691 & 0.782 & 0.714 & 0.217 & 0.285 \\
\hline C-15 & 0.415 & 0.429 & 0.584 & 0.569 & 0.712 & 0.764 & 0.799 & 0.604 & 0.201 & 0.395 \\
\hline GM-6 & 0.399 & 0.375 & 0.600 & 0.624 & 0.687 & 0.601 & 0.893 & 0.585 & 0.106 & 0.414 \\
\hline PM-3 & 0.415 & 0.299 & 0.584 & 0.699 & 0.714 & 0.428 & 0.790 & 0.685 & 0.209 & 0.314 \\
\hline PM-5 & 0.358 & 0.304 & 0.641 & 0.695 & 0.558 & 0.440 & 0.726 & 0.826 & 0.273 & 0.124 \\
\hline KG-2 & 0.302 & 0.321 & 0.697 & 0.678 & 0.438 & 0.474 & 0.743 & 0.607 & 0.256 & 0.392 \\
\hline $\mathrm{C}-4$ & 0.303 & 0.309 & 0.696 & 0.690 & 0.435 & 0.447 & 0.767 & 0.721 & 0.232 & 0.279 \\
\hline Mean & 0.354 & 0.332 & 0.645 & 0.667 & 0.569 & 0.515 & 0.775 & 0.708 & 0.224 & 0.287 \\
\hline C.D $(p \leq 0.05)$ & \multicolumn{2}{|c|}{0.071} & \multicolumn{2}{|c|}{0.073} & \multicolumn{2}{|c|}{0.188} & \multicolumn{2}{|c|}{0.044} & \multicolumn{2}{|c|}{0.040} \\
\hline
\end{tabular}


Table.3 Analysis of variance for various root and shoot parameters and biomass partitioning traits under greenhouse conditions in maize (Zea mays L.) genotypes

\begin{tabular}{|c|c|c|c|c|c|c|c|c|c|c|c|}
\hline $\begin{array}{l}\text { Source of } \\
\text { Variation }\end{array}$ & d.f. & $\begin{array}{c}\text { Plant } \\
\text { Height } \\
\text { (cm) }\end{array}$ & $\begin{array}{c}\text { Shoot } \\
\text { Biomass (g) }\end{array}$ & $\begin{array}{c}\text { Rooting } \\
\text { Depth } \\
\text { (cm) }\end{array}$ & $\begin{array}{c}\text { Root } \\
\text { Biomass (g) }\end{array}$ & $\begin{array}{c}\text { Total } \\
\text { Biomass }\end{array}$ & $\begin{array}{c}\text { Root } \\
\text { Biomass } \\
\text { at Top }\end{array}$ & $\begin{array}{c}\text { Root } \\
\text { Biomass } \\
\text { at } \\
\text { Bottom }\end{array}$ & $\begin{array}{c}\text { Root } \\
\text { to Total } \\
\text { Biomass }\end{array}$ & $\begin{array}{c}\text { Shoot } \\
\text { to Total } \\
\text { Biomass }\end{array}$ & $\begin{array}{c}\text { Root } \\
\text { Shoot } \\
\text { Rato }\end{array}$ \\
\hline Genotypes & 12 & 223.897 & $1461.167 *$ & 374.317 & $232.423 * *$ & $1399.798 *$ & $0.006^{* *}$ & $0.007 * *$ & $0.013 * *$ & $0.013 * *$ & $0.079 * *$ \\
\hline $\begin{array}{l}\text { Water } \\
\text { Regime }\end{array}$ & 1 & $18168.923 * *$ & $154126.173 * *$ & $7705.558 * *$ & $48190.173 * *$ & $374680.692 * *$ & $0.059 * *$ & $0.053 * *$ & $0.006^{* *}$ & $0.006^{* *}$ & $0.037 *$ \\
\hline $\begin{array}{l}\text { Genotype } \\
\text { X Water } \\
\text { Treatment }\end{array}$ & 12 & 180.340 & 717.923 & $715.599^{*}$ & $163.590 * *$ & 1115.567 & $0.017 * *$ & $0.019 * *$ & 0.002 & 0.002 & 0.017 \\
\hline Error & 26 & 129.808 & 620.404 & 359.058 & 23.635 & 799.615 & 0.001 & 0.001 & 0.002 & 0.002 & 0.017 \\
\hline
\end{tabular}

Table.4 Effect of drought on various root and shoot traits and biomass partitioning in maize (Zea mays L.) genotypes

\begin{tabular}{|c|c|c|c|c|c|c|c|c|c|}
\hline Treatment & $\begin{array}{c}\text { Plant } \\
\text { height } \\
\text { (cm) }\end{array}$ & $\begin{array}{c}\text { Shoot } \\
\text { biomass } \\
\text { (g) }\end{array}$ & $\begin{array}{c}\text { Rooting } \\
\operatorname{depth}(\mathrm{cm})\end{array}$ & $\begin{array}{c}\text { Root } \\
\text { biomass } \\
\text { (g) }\end{array}$ & $\begin{array}{c}\text { Root } \\
\text { biomass } \\
\text { at top }(\mathrm{g})\end{array}$ & $\begin{array}{c}\text { Root } \\
\text { biomass } \\
\text { at bottom }(\mathrm{g})\end{array}$ & $\begin{array}{c}\text { Root to } \\
\text { total } \\
\text { biomass }\end{array}$ & $\begin{array}{c}\text { Shoot to } \\
\text { total } \\
\text { biomass }\end{array}$ & $\begin{array}{l}\text { Root shoot } \\
\text { ratio }\end{array}$ \\
\hline Irrigated & 137.846 & 160.692 & 127.538 & 85.884 & 0.775 & 0.224 & 0.354 & 0.667 & 0.515 \\
\hline Drought & 100.461 & 51.807 & 103.192 & 25.000 & 0.707 & 0.287 & 0.332 & 0.644 & 0.568 \\
\hline $\begin{array}{l}\text { Percent } \\
\text { increase } \\
\text { or decrease }\end{array}$ & -27.120 & -67.759 & -19.089 & -70.891 & -8.691 & +28.463 & -6.209 & -3.484 & +9.388 \\
\hline$C D(p \leq 0.05)$ & 6.531 & 14.279 & 10.862 & 2.787 & 0.017 & 0.016 & 0.026 & 0.028 & 0.720 \\
\hline
\end{tabular}


Table.5 Correlation of root and shoot parameters under drought and irrigated conditions in maize (Zea mays L.) genotypes

\begin{tabular}{|c|c|c|c|c|c|c|c|c|c|c|}
\hline Genotype & Treatment & $\begin{array}{l}\text { Plant } \\
\text { height }\end{array}$ & $\begin{array}{l}\text { Shoot } \\
\text { biomass }\end{array}$ & $\begin{array}{l}\text { Root } \\
\text { depth }\end{array}$ & $\begin{array}{l}\text { Root } \\
\text { biomass }\end{array}$ & $\begin{array}{l}\text { Root } \\
\text { biomass } \\
\text { at top }\end{array}$ & $\begin{array}{l}\text { Root } \\
\text { biomass } \\
\text { at bottom }\end{array}$ & $\begin{array}{l}\text { Root to } \\
\text { total } \\
\text { biomass }\end{array}$ & $\begin{array}{l}\text { Shoot to } \\
\text { total } \\
\text { biomass }\end{array}$ & $\begin{array}{l}\text { Root } \\
\text { shoot } \\
\text { ratio }\end{array}$ \\
\hline \multirow[t]{2}{*}{$\begin{array}{l}\text { Plant } \\
\text { height }\end{array}$} & Irrigated & - & $0.556^{*}$ & 0.032 & $-0.447 *$ & $-0.449 *$ & $0.447 *$ & $-0.698 *$ & $0.698 *$ & $-0.679 *$ \\
\hline & Drought & - & $0.675^{*}$ & $\begin{array}{l}- \\
0.146\end{array}$ & $0.719 *$ & -0.129 & $0.181 *$ & 0.044 & -0.045 & 0.073 \\
\hline \multirow[t]{2}{*}{$\begin{array}{l}\text { Shoot } \\
\text { biomass }\end{array}$} & Irrigated & & - & 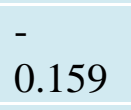 & -0.125 & -0.018 & 0.017 & $-0.787 *$ & $0.787 *$ & $-0.772 *$ \\
\hline & Drought & & - & $\begin{array}{l}- \\
0.127\end{array}$ & $0.287^{*}$ & 0.064 & -0.013 & $-0.587 *$ & $0.593^{*}$ & $-0.547 *$ \\
\hline \multirow{2}{*}{$\begin{array}{l}\text { Root } \\
\text { depth }\end{array}$} & Irrigated & & & - & -0.070 & 0.047 & -0.047 & 0.137 & -0.137 & $0.227 *$ \\
\hline & Drought & & & - & -0.065 & $0.393^{*}$ & $-0.379 *$ & 0.067 & -0.068 & 0.054 \\
\hline \multirow{2}{*}{$\begin{array}{l}\text { Root } \\
\text { biomass }\end{array}$} & Irrigated & & & & - & $0.442 *$ & $-0.442 *$ & $0.700 *$ & $-0.700 *$ & $0.686^{*}$ \\
\hline & Drought & & & & - & $-0.492 *$ & $0.503 *$ & $0.584 *$ & $-0.579 *$ & $0.604 *$ \\
\hline \multirow{2}{*}{$\begin{array}{l}\text { Root } \\
\text { biomass } \\
\text { at top }\end{array}$} & Irrigated & & & & & - & $-0.999 *$ & $0.318 *$ & $-0.318^{*}$ & $0.300 *$ \\
\hline & Drought & & & & & - & $-0.988 *$ & $-0.439 *$ & $0.434 *$ & $-0.439 *$ \\
\hline \multirow{2}{*}{$\begin{array}{l}\text { Root } \\
\text { biomass } \\
\text { at bottom }\end{array}$} & Irrigated & & & & & & - & $-0.317 *$ & $0.317^{*}$ & $-0.299 *$ \\
\hline & Drought & & & & & & - & $0.421 *$ & $-0.415^{*}$ & $0.425^{*}$ \\
\hline \multirow{2}{*}{$\begin{array}{l}\text { Root to } \\
\text { total } \\
\text { Biomass }\end{array}$} & Irrigated & & & & & & & - & $-0.999 *$ & $0.991 *$ \\
\hline & Drought & & & & & & & - & $-0.999 *$ & $0.993 *$ \\
\hline \multirow{2}{*}{$\begin{array}{l}\text { Shoot to } \\
\text { total } \\
\text { Biomass }\end{array}$} & Irrigated & & & & & & & & - & $-0.991 *$ \\
\hline & Drought & & & & & & & & - & $-0.990 *$ \\
\hline \multirow{2}{*}{$\begin{array}{l}\text { Root shoot } \\
\text { Ratio }\end{array}$} & Irrigated & & & & & & & & & - \\
\hline & Drought & & & & & & & & & - \\
\hline
\end{tabular}


Fig.1 Root of Maize (Zea mays L.) genotypes under drought and irrigated conditions
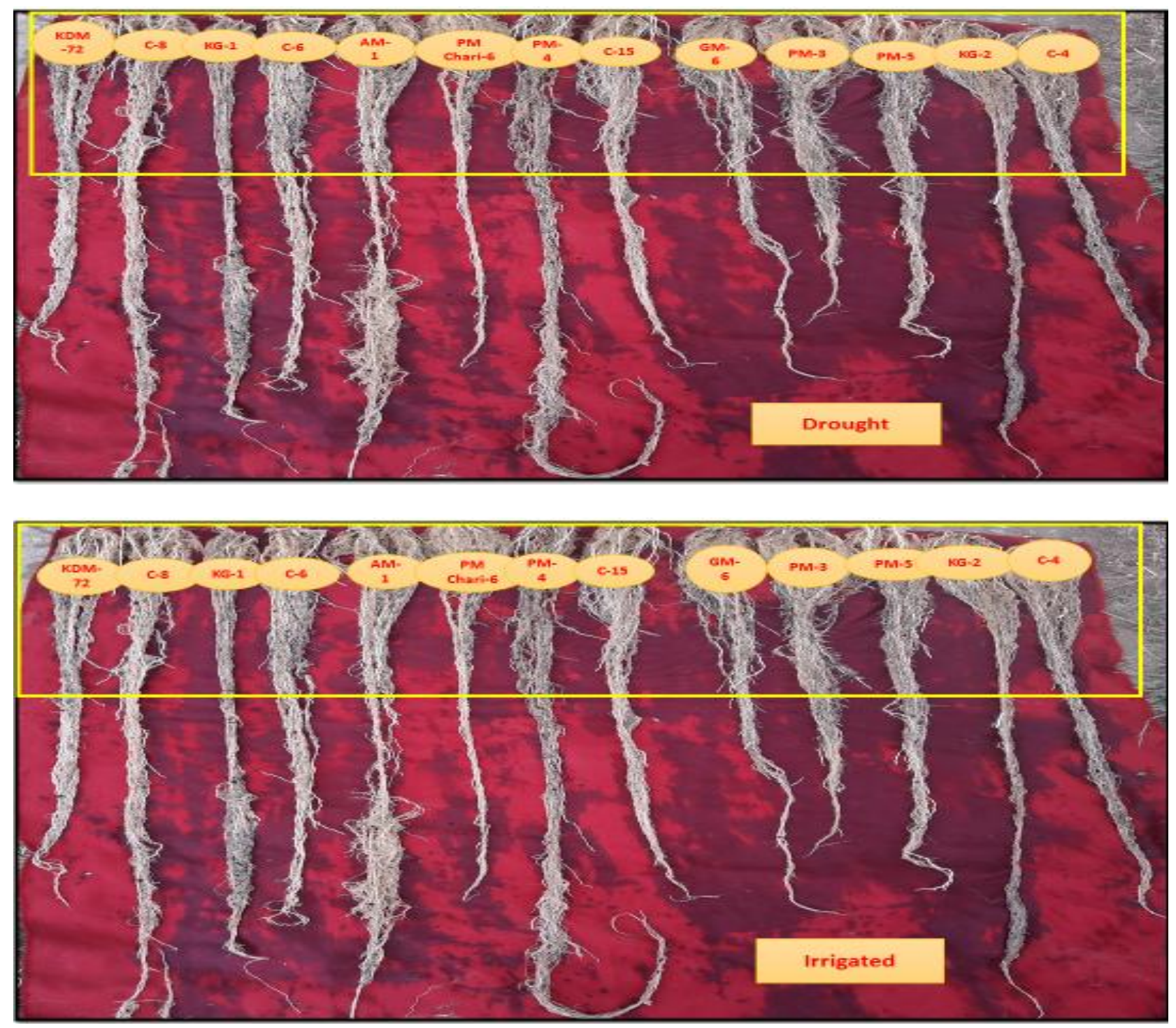
However under irrigated condition plant height had significant positive correlation with shoot to total biomass (0.698) followed by shoot biomass $(0.556)$ and root biomass at bottom (0.447).

\section{Shoot biomass}

Under drought condition shoot biomass had significant positive correlation with shoot to total biomass (0.593) and root biomass (0.287). However under irrigated condition shoot biomass had significant positive correlation with shoot to total biomass (0.787).

\section{Rooting depth}

Under drought condition root depth had significant positive correlation with root biomass at top (0.393). However under irrigated condition root depth had significant positive correlation with root shoot ratio (0.227).

\section{Root biomass}

Under drought condition root biomass had significant positive correlation with root shoot ratio $(0.604)$ followed by root to total biomass (0.584) and root biomass at bottom (0.503). However under irrigated condition root biomass had significant positive correlation with root to total biomass (0.700) followed by root shoot ratio $(0.686)$ and root biomass at top (0.442).

\section{Root biomass at top}

Under drought condition root biomass at top had significant positive correlation with shoot to total biomass (0.434). However under irrigated condition root biomass at top had significant positive correlation with root to total biomass (0.318) and root shoot ratio (0.300).

\section{Root biomass at bottom}

Under drought condition root biomass at bottom had significant positive correlation with root shoot ratio $(0.425)$ and root to total biomass (0.421).

However under irrigated condition root biomass at bottom had significant positive correlation with shoot to total biomass (0.317).

\section{Root to total biomass}

Under drought condition root to total biomass had significant positive correlation with root shoot ratio (0.993).

However under irrigated condition root to total biomass had significant positive correlation with root shoot ratio (0.991).

\section{Negative correlations}

\section{Plant height}

Under irrigated condition plant height had significant negative correlation with root to total biomass (0.698) followed by root shoot ratio (0.679) and root biomass (0.447).

\section{Shoot biomass}

Under drought condition shoot biomass had significant negative correlation with root to total biomass (0.587) and root shoot ratio (0.547). Under irrigated conditions shoot biomass had significant negative correlation with root to total biomass (0.787) and root shoot ratio (0.772).

\section{Rooting depth}

Under drought condition root depth had significant negative correlation with root biomass at bottom (0.379). 


\section{Root biomass}

Under drought condition root biomass had significant negative correlation with shoot to total biomass (0.579) and root biomass at top (0.492). However under irrigated condition root biomass had significant negative correlation with shoot to total biomass $(0.700)$ and root biomass at bottom (0.442).

\section{Root biomass at top}

Under drought condition root biomass at top had significant negative correlation with root biomass at bottom (0.988) followed by root to total biomass (0.439) and root shoot ratio (0.439). However under irrigated condition root biomass at top had significant negative correlation with root biomass at bottom (0.999) and shoot to total biomass (0.318).

\section{Root biomass at bottom}

Under drought condition root biomass at bottom had significant negative correlation with shoot to total biomass (0.415). Under irrigated condition root biomass at bottom had significant negative correlation with root to total biomass (0.317) and root shoot ratio (0.299).

\section{Root to total biomass}

Under drought condition root to total biomass had significant negative correlation with shoot to total biomass (0.999). However under irrigated condition root to total biomass had significant negative correlation with shoot to total biomass (0.999).

\section{Shoot to total biomass}

Under drought condition shoot to total biomass had significant negative correlation with root shoot ratio (0.990). However under irrigated condition shoot to total biomass had significant negative correlation with root shoot ratio (0.991).

Studying root architecture extensively under field condition is limited due to the expenditure of time and labor involved in destructive techniques like the core method, and the likelihood of under-estimation of root depth and density with alternative method like minirhizotron (Vamerali et al., 2012). To circumvent these constraints, we used a simple and inexpensive system including soil media that allowed root growth in order to identify a medium which supports the best maize root growth for our future studies and easy extraction of intact roots. Overall, our experimental results suggest that root length, root biomass at bottom and root shoot ratio are related and are implicated with drought tolerance, but root biomass at bottom could be used as a more reliable trait for selection for drought tolerance in maize. Further studies in greenhouse and in field as well are required using a larger panel of genotypes to validate this kind of association.

\section{References}

Aslam, M., Zamir, M.S.I., Afzal, I., Yaseen, M., Mubeen, M. and Shoaib, A. 2013. Drought stress, its effect on maize production and development of drought tolerance through potassium application. Cercetari Agronomice in Moldova 46(2): 99-114.

Beebe, S.E. and Smith, C. 2014. Selection for drought tolerance in common beans. Crop Science 48(2): 582-592.

Burton, A.L. Brown, K.M. and Lynch, J.P. 2013. Phenotypic diversity of root anatomical and architectural traits in species. Crop Science 53(3): 10421055.

Chaves, M.M., Maroco, J.P. and Pereira, J.S. 2003. Understanding plant responses to drought-from genes to the whole 
plant. Functional Plant Biology, 30(3): 239-264.

Comas, L.H., Becker, S.R., Von Mark, V.C., Byrne, P.F. and Dierig, D.A. 2013. Root traits contributing to plant productivity under drought. Ecophysiology of Root Systems-Environment Interaction, 18.

De Dorlodot, S., Forster, B., Pagès, L., Price, A., Tuberosa, R. and Draye, X. 2007. Root system architecture: opportunities and constraints for genetic improvement of crops. Trends in Plant Science, 12: 474-481.

Dwyer, L.M., Stewart, D.W. and Balchin, D. 1988. Rooting characteristics of corn, soybeans and barley as a function of available water and soil physical characteristics. Canadian Journal of Soil Science, 68(1): 121-132.

Eggball, B. and Maranville, J.W. 1993. Root development and nitrogen influx of corn genotypes grown under combined drought and nitrogen stress. Agronomy Journal, 85(1): 147-152.

Fukai, S., Cooper, M. (1995). Development of drought-resistant cultivars using physiomorphological traits in rice. Field Crops Research, 40: 67-86.

Gonzales, W.L., Suarez, L.H., MolinaMontenegro, M.A. and Gianoli, E. 2008. Water availability limits tolerance of apical damage in the Chilean tarweed Madia sativa. Acta Oecologica, 34(1): 104-110.

Gowda, V.R.P., Henry, A., Yamauchi, A., Shashidhar, H.E., Serraj, R. (2011). Root biology and genetic improvement for drought avoidance in rice. Field Crops Research, 122:1-13.

Grace, J. 1997. Plant water relations. Plant Ecology 28-50.

Huang, T.K., Han, C.L., Lin, S.I., Chen, Y.J., Tsai, Y.C., Chen, Y.R., Chen, J.W., Lin, W.Y., Chen, P.M., Liu, T.Y. and Chen, Y.S. 2013. Identification of downstream components of ubiquitin-conjugating enzyme PHOSPHATE2 by quantitative membrane proteomics in Arabidopsis roots. The Plant Cell, 25(10): 40444060.

Hund, A., Ruta, N. and Liedgens, M. 2009. Rooting depth and water use efficiency of tropical maize inbred lines, differing in drought tolerance. Plant and Soil, 318(1): 311-325.

Kell, D., B. (2011). Breeding crop plants with deep roots: their role in sustainable carbon, nutrient and water sequestration. Annals of Botany.

Kondo, M., P. Pablico, D. Aragones, R. Agbisit, J. Abe, S. Morita and B. Courtois (2003). Genotypic and environmental variations in root morphology in rice genotypes under upland field conditions. In: Abe, J. (ed.) Roots: The Dynamic Interface between Plants and the Earth, Kluwer Academic Publisher, The Netherlands, pp. 189200.

Kumar, B., Abdel- Ghani, A.H., Reyes- Matamoros, J., Hochholdinger, F. and Lübberstedt, T. 2012. Genotypic variation for root architecture traits in seedlings of maize (Zea mays L.) inbred lines. Plant Breeding, 131(4): 465-478.

Leach, K.A., L.G. Hejlek, L.B. Hearne, H.T. Nguyen, R.E. Sharp and G.L. Davis. (2011). Primary root elongation rate and abscisic acid levels of maize in response to water stress. Crop Sciences, 51: 157172.

Liang, Y.S., Zhan, X.D., Wang, H.M., Gao, Z.Q., chuan Lin, Z., Chen, D.B., Shen, X.H., Cao, L.Y. and Cheng, S.H. 2013. Locating QTLs controlling several adult root traits in an elite Chinese hybrid rice. Gene 526(2): 331-335.

Ludlow, M.M., Muchow, R.C. (1990). A critical evaluation of traits for improving crop yields in water-limited environments. Advance Agronomy 43:107-153 
Lynch, J.P. 2013. Steep, cheap and deep: an ideotype to optimize water and $\mathrm{N}$ acquisition by maize root systems. Annals of Botany 112(2): 347357.

Malamy, J.E. and P.N. Benfey (1997). Organization and cell differentiation in lateral roots of Arabidopsis thaliana. Development 124: 33-44.

Manschadi, A.M., Christopher, J. and Hammer, G.L. 2006. The role of root architectural traits in adaptation of wheat to water-limited environments. Functional Plant Biology 33(9): 823-837.

McCully, M.E. (1999). Roots in soil: unearthing the complexities of roots and their rhizospheres. Annual Revised Plant Physiology Plant Molecular Biology 50:695-718.

Ober, E.S. and R.E. Sharp. (2007). Regulation of root growth responses to water deficit. In: Jenks, M.A., P.M. Hasegawa and S.M. Jain (eds.) Advances in Molecular Breeding Toward Drought and Salt Tolerant Crops, Springer, The Netherlands, pp. 33-54.

Ogawa, A., Kawashima, C. and Yamauchi, A. 2005. Sugar accumulation along the seminal root axis, as affected by osmotic stress in maize: a possible physiological basis for plastic lateral root development. Plant Production Science 8(2): 173-180.

Passioura, J.B. 2012. Phenotyping for drought tolerance in grain crops: when is it useful to breeders? Functional Plant Biology 39(11): 851-859.

Pingali, P.L. (2001). CIMMYT 1999-2000 World Maize Facts and Trends. Meeting World Maize Needs: Technological Opportunities and Priorities for the Public Sector. CIMMYT Mexico, DF.

Quarrie, S.A. (1996). New molecular tools to improve the efficiency of breeding for increased drought resistance. Plant Growth Regulation 20:167-178.

Quezada, I.M. and Gianoli, E. 2010. Counteractive biomass allocation responses to drought and damage in the perennial herb Convolvulus demissus. Austral Ecology 35(5): 544548.

Rao, I., Klaedtke, S.M., Cajiao, C., Grajales, M., Polania, J., Borrero, G., Guerrero, A., Rivera, M., Beebe, S.E. and Leon, J. 2012. Photosynthate remobilization capacity from drought-adapted common bean (Phaseolus vulgaris L.) lines can improve yield potential of interspecific populations within the secondary gene pool. Journal of Plant Breeding and Crop Science 4(4): 49-61.

Ribaut, J.-M., J. Betran, P. Monneveux and T. Setter (2009). Drought tolerance in maize. In: Bennetzen, J.L. and S.C. Hake (eds.) Handbook of Maize: Its Biology, Springer, New York, pp. 311344.

Serraj, R., Kumar, A., McNally, K.L., SlametLoedin, I., Bruskiewich, R., Mauleon, R., Cairns, J., Hijmans, R.J. (2009). Improvement of drought resistance in rice. Advance Agronomy 103:41-98.

Sharp, R.E., V. Poroyko, L.G. Hejlek, W.G. Spollen, G.K. Springer, H.J. Bohnert and H.T. Nguyen. (2004). Root growth maintenance during water deficits: physiology to functional genomics. Journal of Experimental Botany 55: 2343-2351.

Trachsel, S., P. Stamp and A. Hund. (2010). Growth of axile and lateral roots of maize: Response to desiccation stress induced by polyethylene glycol 8000 . Maydica 55: 101-109.

Tuberosa, R., Sanguineti, M.C., Landi, P., Giuliani, M.M., Salvi, S. and Conti, S. 2002. Identification of QTLs for root characteristics in maize grown in hydroponics and analysis of their 
overlap with QTLs for grain yield in the field at two water regimes. Plant Molecular Biology, 48(5-6): 697-712.

Vadez, V. (2014). Root hydraulics: The forgotten side of roots in drought adaptation. Field Crops Research, 165: $15-24$.

Vadez, V., Rao, S., Kholova, J., Krishnamurthy, L., Kashiwagi, J., Ratnakumar, P., Sharma, K. K., Bhatnagar-Mathur, P. and Basu, P. S. 2008. Roots research for legume tolerance to drought. Journal of Food Legumes, 21: 77-85.

Vamerali, T., Bandiera, M., Mosca, G. (2012). Minirhizotrons in modern root studies. In: Mancuso S (ed) Measuring roots. Springer, Berlin, pp 341-361.
Vegh, K.R. (2013). Root and leaf traits, water use and drought tolerance of maize genotypes. Biologia, 68: 11231127.

Wasson, A.P., Richards, R.A., Chatrath, R., Misra, S.C., Prasad, S.S., Rebetzke, G.J., Kirkegaard, J.A., Christopher, J. and Watt, M. 2012. Traits and selection strategies to improve root systems and water uptake in water-limited wheat crops. Journal of Experimental Botany, 63(9): 3485-3498.

Zhu, J., Brown, K.M. and Lynch, J.P. 2010. Root cortical aerenchyma improves the drought tolerance of maize (Zea mays L.). Plant, Cell \& Environment, 33(5): 740-749.

\section{How to cite this article:}

Dar, I.A., P.A. Sofi, Z.A. Dar, Kamaluddin and Lone, A.A. 2018. Screening of Maize Genotypes for Drought Tolerance Related Trait Variability. Int.J.Curr.Microbiol.App.Sci. 7(04): 668-682. doi: https://doi.org/10.20546/ijcmas.2018.704.076 